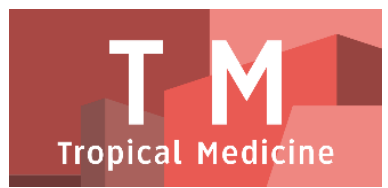

PAPER - OPEN ACCESS

\title{
Beban Pengasuhan yang Dialami Oleh Orangtua yang Memiliki Anak dengan Gangguan Spektrum Autis
}

\author{
Author : Desvi Yanti Mukhtar \\ DOI $\quad: 10.32734 /$ tm.v1i1.42 \\ Paper Page : $163-170$
}

Volume 1 Issue 1 - 2018 TALENTA Conference Series: Tropical Medicine (TM)

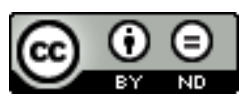

This work is licensed under a Creative Commons Attribution-NoDerivatives 4.0 International License.

Published under licence by TALENTA Publisher, Universitas Sumatera Utara
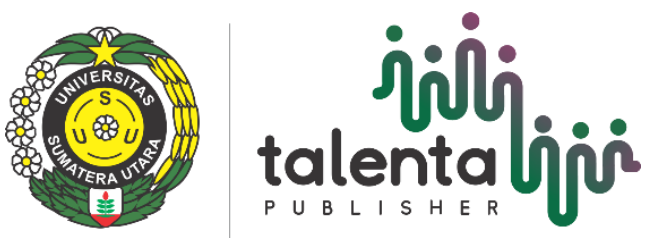


\title{
Beban Pengasuhan yang Dialami Oleh Orangtua yang Memiliki Anak dengan Gangguan Spektrum Autis
}

\author{
Desvi Yanti Mukhtar*, Amitya Kumara ${ }^{\mathrm{b}}$, T. Dicky Hastjarjo ${ }^{\mathrm{b}}$, M. G. Adiyanti ${ }^{\mathrm{b}}$ \\ ${ }^{a}$ Fakultas Psikologi, Universitas Sumatera Utara, Medan, Indonesia \\ ${ }^{b}$ Fakultas Psikologi, Universitas Gadjah Mada, Yogyakarta, Indonesia \\ adesvi.ym@gmail.com
}

\begin{abstract}
Abstrak
Penelitian ini bertujuan untuk mengetahui beban yang dialami oleh orangtua dalam mengasuh anak dengan gangguan spektrum autis. Hasil penelitian ini diharapkan dapat membantu tenaga profesional dalam memberikan dukungan bagi orangtua yang memiliki anak autis. Penelitian ini merupakan penelitian deskriptif yang menggunakan metode campuran sekuensial. Pengumpulan data dilakukan dengan menggunakan teknik kelompok terarah dan angket. Pada tahap pertama, penelitian ini melibatkan 7 responden (6 ibu, 1 ayah) sedangkan tahap kedua 31 responden (18 ibu, 13 ayah).

Hasil penelitian menunjukkan bahwa orangtua yang memiliki anak dengan gangguan autis mengalami beban pengasuhan yang dapat dikelompokkan dalam tiga dimensi. Pertama, beban yang terkait dengan aspek personal orangtua yaitu munculnya masalah-masalah psikologis seperti merasa malu dengan kondisi anak, muncul perasaan bersalah, atau merasa jenuh dengan kehidupan yang dijalani. Kedua, beban yang terkait dengan hambatan yang dialami anak autis seperti kesulitan mengontrol perilaku dan emosi anak. Dan ketiga, beban yang terkait dengan peran pengasuhan secara umum, misalnya menjadi sering bertengkar dengan pasangan. Hasil penelitian juga menunjukkan ada beberapa faktor yang membantu menguatkan orangtua dalam mengasuh anak autis. Pertama, faktor personal seperti adanya keikhlasan menerima kondisi anak, kedekatan pada Tuhan, serta cara berpikir yang positif. Kedua, adanya dukungan sosial terutama yang didapat dari pasangan.
\end{abstract}

Kata Kunci: beban pengasuhan; anak dengan gangguan spektrum autis

\section{Pendahuluan}

Pengasuhan anak merupakan tugas yang paling penting sekaligus paling sulit dan kompleks bagi orangtua [3];[24]. Ada beberapa alasan mengapa tugas mengasuh anak tergolong penting sekaligus sulit dan kompleks. Pertama, karena kualitas pengasuhan akan sangat mempengaruhi bagaimana perkembangan anak, misalnya karakter dan kompetensinya [2]. Kedua, tugas mengasuh anak tidak hanya berkaitan dengan merawat atau membesarkan anak, tetapi juga berkaitan dengan melakukan proses sosialisasi atau penanaman nilai pada anak [33]. Dan ketiga, tugas pengasuhan anak tidak hanya bersifat dyadic dengan anak, tetapi bersifat polyadic karena dipengaruhi oleh berbagai konteks perkembangan [3];[20].

Kesulitan dan kompleksitas dalam mengasuh anak seringkali menimbulkan beban pengasuhan bagi orangtua. Beban pengasuhan adalah dampak negatif atau permasalahan yang muncul sebagai konsekuensi dari proses merawat dan mengasuh anak [17]. Schwartz [27] menyatakan bahwa istilah beban pengasuhan merujuk pada dua 
hal. Pertama, beban secara objektif yaitu adanya kesulitan dalam aktivitas keseharian, dan kedua, beban secara subjektif yaitu munculnya masalah emosi dan mental pada orangtua.

Menurut Berns [3] kesulitan dan kompleksitas dalam mengasuh anak akan lebih besar dialami oleh orangtua ketika mereka mengasuh anak yang berkebutuhan khusus, misalnya anak dengan gangguan spektrum autis. Menurut Diagnostic and Statistical Manual of Mental Disorder edisi 5 atau DSM-5 (American Psychiatric Association, 2013) [1], gangguan spektrum autis merupakan gangguan perkembangan syaraf yang ditandai dengan dua karakteristik utama, yaitu adanya hambatan dalam komunikasi dan interaksi sosial serta adanya tingkah laku, minat, dan aktivitas yang bersifat stereotip atau berulang.

Hasil penelitian menunjukkan ada banyak beban atau permasalahan yang dapat dialami oleh orangtua yang mengasuh anak dengan gangguan spektrum autis. Salah satu permasalahan yang paling banyak terjadi adalah terganggunya kesejahteraan psikologis orangtua seperti timbulnya stres. Beberapa penelitian secara konsisten menunjukkan bahwa orangtua yang memiliki anak autis mengalami tingkat stres yang lebih tinggi dibandingkan dengan orangtua yang memiliki anak dengan gangguan perkembangan lainnya [19];[26]. Permasalahan psikologis lain yang juga dialami orangtua adalah timbulnya rasa duka dan marah [18], timbulnya rasa bersalah [4] atau merasa terisolasi dari lingkungan karena adanya stigma negatif tentang gangguan spektrum autis [4].

Beban lain yang juga dialami orangtua adalah banyaknya energi dan waktu yang tersita untuk mengurus anak autis [31], terganggunya pekerjaan [29], terbatasnya interaksi dan sosialisasi mereka dengan lingkungan [15], berkurangnya perhatian orangtua terhadap saudara anak autis [11], serta rendahnya kepuasan dalam hubungan keluarga [28].

Beratnya beban pengasuhan yang dihadapi orangtua dalam mengasuh anak autis dapat berdampak negatif, baik pada orangtua sendiri, maupun pada anak. Dibutuhkan sebuah dukungan yang dapat membantu mereka beradaptasi terhadap beban pengasuhan tersebut. Menurut Miller dan Hudson [21] serta Moran, Ghate, dan Merwe [23], dukungan bagi orangtua sebaiknya disesuaikan dengan kebutuhan orangtua. Hal ini dapat dilakukan dengan cara melakukan asesmen kebutuhan dan permasalahan yang dihadapi, karena mungkin saja permasalahan antara orangtua yang satu berbeda dengan orangtua lainnya. Perbedaan ini tidak terlepas dari pengaruh lingkungan atau ekosistem orangtua yang juga berbeda, seperti latar belakang budaya dan agama, kondisi ekonomi, karakteristik keluarga dan sebagainya.

Berdasarkan pertimbangan tersebut, penelitian ini bertujuan untuk mendapatkan gambaran mengenai beban pengasuhan yang dialami orangtua dalam mengasuh anak autis, khususnya yang berada di Kota Medan. Melalui penelitian ini diharapkan akan didapatkan data mengenai apa saja beban yang dirasakan orangtua serta faktor-faktor apa yang mempengaruhi kemampuan mereka untuk lebih kuat dalam beradaptasi terhadap beban tersebut. Data yang didapat melalui penelitian ini diharapkan dapat dijadikan pertimbangan oleh profesional dalam memberikan dukungan kepada mereka.

\section{Metode Penelitian}

Penelitian ini merupakan penelitian deskriptif yang menggunakan metode campuran sekuensial [5]. Pengumpulan data diawali dengan metode kualitatif menggunakan teknik kelompok terarah (focus group). Menurut Neuman [25], kelompok terarah adalah teknik penelitian kualitatif khusus dengan cara "mewawancarai" secara informal orangorang dalam suatu latar diskusi kelompok. Pada tahap kedua, penelitian dilakukan dengan pendekatan kuantitatif menggunakan metode angket. 


\subsection{Subjek Penelitian}

Subjek dalam penelitian ini adalah orangtua yang memiliki anak dengan gangguan spektrum autis. Pada tahap pertama, responden yang terlibat adalah tujuh orangtua yang anaknya mendapat terapi di salah satu lembaga terapi di Medan, Sumatera Utara, terdiri dari 6 ibu dan 1 ayah. Usia responden berkisar antara 29 tahun - 42 tahun dan rentang usia anak yang mengalami gangguan autis antara 3 tahun -10.5 tahun.

Pada tahap kedua, responden yang terlibat berjumlah 31 orangtua, terdiri dari 18 ibu dan 13 ayah. Diantara ke-31 responden, 5 orang memiliki pendidikan setingkat SMA/sederajat, 23 orang berpendidikan diploma/sarjana, dan 3 orang berpendidikan pascasarjana. Rentang usia responden mulai dari 28 tahun - 49 tahun dan rentang usia anak yang mengalami gangguan autis mulai dari 2 tahun 8 bulan -13 tahun.

\subsection{Prosedur Penelitian}

Penelitian diawali dengan melakukan diskusi kelompok terarah pada tujuh responden yang anaknya mendapat terapi di salah satu tempat terapi di Medan, Sumatera Utara. Data yang diperoleh pada tahap ini dianalisis dengan menggunakan teknik penyandian (coding). Menurut Neuman [25], teknik penyandian dilakukan dengan mengorganisir data mentah menjadi kategori yang didasarkan pada tema atau konsep tertentu. Data dikelompokkan dalam dua tema besar, yaitu bentuk beban pengasuhan yang dialami orangtua dan faktor-faktor yang mempengaruhi orangtua untuk lebih kuat dalam beradaptasi terhadap beban pengasuhan tersebut.

Hasil pengolahan data diskusi kelompok terarah ini kemudian dibuat dalam bentuk angket. Angket terdiri dari dua bagian. Bagian pertama, mengungkap beban pengasuhan yang dialami orangtua, terdiri dari 22 item dengan skoring berkisar antara 1 - 5 setiap itemnya. Bagian kedua, mengungkap faktor- faktor yang dinilai berpengaruh bagi responden dalam beradaptasi terhadap beban pengasuhan. Bagian kedua ini terdiri dari 14 item yang dibagi menjadi dua, 7 item mengungkap faktor personal orangtua dan 7 item lagi mengungkap faktor dukungan sosial. Responden diminta untuk memberi ranking pada masing-masing faktor dimulai dari yang dinilai sangat membantu (ranking 1) sampai yang dinilai kurang membantu (ranking 8). Angket diberikan kepada orang tua, ada yang secara langsung dan ada juga yang melalui lembaga terapi yang menangani anak. Dari 50 angket yang dibagikan, hanya 38 yang kembali dan 31 yang memenuhi syarat untuk diolah secara statistik. Teknik analisa data yang digunakan adalah statistik deskriptif.

\section{Hasil Penelitian}

Hasil penelitian ini dikelompokkan dalam dua bahasan utama. Pertama, yang terkait dengan beban pengasuhan yang dialami orangtua anak autis, dan kedua, faktor yang mempengaruhi kemampuan orangtua untuk beradaptasi terhadap beban pengasuhan tersebut.

\subsection{Beban Pengasuhan yang Dialami Orangtua yang Mengasuh Anak Autis}

Berdasarkan hasil diskusi kelompok terarah, peneliti menemukan beberapa beban pengasuhan yang dialami orangtua terkait dengan peran mereka sebagai pengasuh anak autis. Beban pengasuhan tersebut dapat dikelompokkan dalam tiga dimensi. Pertama, beban yang berkaitan dengan aspek personal orangtua, yaitu munculnya masalah-masalah psikologis seperti sulit menerima diagnosa yang diberikan pada anak, merasa malu dengan kondisi anak, merasa hampa dan kehilangan harapan karena kondisi anak tidak seperti yang diinginkan, munculnya perasaan bersalah terhadap diri sendiri, terkadang menyalahkan Tuhan atas kondisi yang dialami anak dan keluarga, timbul perasaan tertekan, merasa tidak mampu menjadi orangtua, menjadi lebih emosional sehingga kesulitan mengontrol emosi, serta merasa jenuh dengan kehidupan yang dijalani. 
Kedua, beban yang muncul akibat adanya hambatan yang dialami anak. Contohnya adalah kesulitan dalam mengontrol perilaku anak, kesulitan dalam menjalin kedekatan dan interaksi yang hangat dengan anak, kesulitan memahami apa yang diinginkan anak, kebingungan dalam menghadapi anak, dan kesulitan dalam mengontrol emosi anak.

Ketiga, beban yang terkait dengan peran yang harus dijalani orang tua. Misalnya, orangtua jadi sering bertengkar atau berbeda pendapat dengan pasangan dalam mengasuh atau memberi penanganan untuk anak, orangtua tidak mendapatkan dukungan dari pasangan, keluarga besar atau lingkungan dalam mengasuh anak, orangtua jadi lebih banyak fokus pada anaknya yang autis sehingga menimbulkan kecemburuan pada saudara anak yang lain, orangtua jadi tidak punya waktu untuk diri sendiri maupun untuk bersosialisasi karena waktunya tersita untuk mengasuh anak, serta terganggunya pekerjaan karena orangtua harus menyediakan waktu yang banyak untuk mengasuh atau mencari penanganan yang tepat bagi anak.

Berdasarkan analisis dengan stastistik deskriptif, diperoleh nilai rerata beban pengasuhan sebesar $\bar{x}=53.61$ dan standar deviasi $\square=15.40$. Rerata beban pengasuhan empirik ini lebih rendah dibandingkan rerata hipotetik $(\bar{x}=$ $53.61>\bar{x}=66$ ). Bila dikategorisasikan, tingkat beban pengasuhan yang dialami keseluruhan responden berkisar antara sangat rendah sampai tinggi, seperti yang terlihat pada tabel 1 berikut ini.

Tabel 1. Kategorisasi tingkat beban pengasuhan yang dialami keseluruhan responden

\begin{tabular}{lllll}
\hline Kategori & Norma Kategorisasi & \multicolumn{2}{l}{ Jumlah dan } & \\
& & Persentase & Total \\
\hline Sangat rendah & $\mathrm{X} \leq(\mu-1.5 \sigma)$ & $5(28 \%)$ & $7(54 \%)$ & $12(39 \%)$ \\
Rendah & $(\mu-1.5 \sigma)<\mathrm{X} \leq(\mu-0.5 \sigma)$ & $3(17 \%)$ & $2(15 \%)$ & $5(16 \%)$ \\
Sedang & $(\mu-0.5 \sigma)<\mathrm{X} \leq(\mu+0.5 \sigma)$ & $6(33 \%)$ & $3(23 \%)$ & $9(29 \%)$ \\
Tinggi & $(\mu+0.5 \sigma)<\mathrm{X} \leq(\mu+1.5 \sigma)$ & $4(22 \%)$ & $1(8 \%)$ & $5(16 \%)$ \\
Sangat tinggi & $(\mu+1.5 \sigma)<\mathrm{X}$ & 0 & 0 & 0 \\
Jumlah & & $18(100 \%)$ & $13(100 \%)$ & $31(100 \%)$ \\
\hline
\end{tabular}

Diantara 22 beban pengasuhan yang diungkap dalam angket, beban yang memiliki rerata rating paling tinggi adalah kesulitan dalam memahami apa yang dibutuhkan anak $(\bar{x}=3.13)$, tidak punya waktu untuk diri sendiri $(\bar{x}=3.06)$, kesulitan mengontrol perilaku anak $(\bar{x}=3.03)$, kesulitan mengontrol emosi sendiri $(\bar{x}=$ 2.94), terjadi perbedaan pendapat dengan keluarga besar dalam menghadapi anak $(\bar{x}=2.94)$, bertengkar dengan pasangan karena berbeda pendapat dalam menghadapi anak $(\bar{x}=2.87)$, dan timbul kecemburuan pada saudara anak yang autis $(\bar{x}=2.81)$.

Ditinjau dari jenis kelamin, beban pengasuhan yang dirasakan oleh ibu $\left(\bar{x}=^{-}\right.$57.61) lebih tinggi dibandingkan dengan yang dirasakan oleh ayah $(\bar{x}=48.08)$. Ibu dan ayah juga memiliki perbedaan dalam merating lima beban pengasuhan yang dianggap paling berat, seperti terlihat pada tabel 2 berikut. 
Tabel 2. Perbedaan penilaian beban pengasuhan antara ibu dan ayah

\begin{tabular}{|c|c|c|c|c|}
\hline \multirow[t]{2}{*}{ No } & \multicolumn{2}{|l|}{ Ibu } & \multicolumn{2}{|l|}{ Ayah } \\
\hline & Beban Pengasuhan & $\bar{x}$ & Beban Pengasuhan & $\bar{x}$ \\
\hline 1 & Tidak punya waktu untuk diri sendiri & 3.33 & Kesulitan memahami apa yang diinginkan anak & 3.08 \\
\hline 3 & Kesulitan memahami apa yang diinginkan anak & 3.17 & Kesulitan mengontrol emosi dalam menghadapi anak & 2.77 \\
\hline 4 & $\begin{array}{l}\text { Berbeda pendapat dengan keluarga besar dalam } \\
\text { menghadapi anak }\end{array}$ & 3.17 & Kesulitan mengontrol perilaku anak & 2.77 \\
\hline 5 & $\begin{array}{l}\text { Kesulitan mengontrol emosi dalam menghadapi } \\
\text { anak }\end{array}$ & 3.06 & Tidak punya waktu untuk diri sendiri & 2.69 \\
\hline
\end{tabular}

\subsection{Faktor yang Menguatkan Orangtua untuk Beradaptasi terhadap Beban Pengasuhan}

Hasil penelitian menunjukkan beberapā faktor yang mempengaruhi kemampuan orangtua untuk beradaptasi terhadap beban pengasuhan yang mereka alami. Berdasarkan data yang diperoleh melalui diskusi kelompok terarah, hal-hal yang mempengaruhi proses adaptasi orangtua terhadap beban pengasuhan dapat ${ }^{-}$ dikelompokkan menjadi dua faktor, yaitu karakteristik personal orangtua dan dukungan sosial yang diterima. Berdasarkan hasil analisis deskriptif, karakteristik personal orangtua yang secara umum memiliki rangking paling tinggi adalah keikhlasan menerima kondisi anak $(\bar{x}=1.94)$, kedekatan dengan Tuhan $(\bar{x}=2.50)$, kemampuan memahami kebutuhan atau keinginan anak $(\bar{x}=3.44)$, dan cara berpikir yang positif $(\bar{x}=3.50)$.

Ditinjau dari faktor dukungan sosial yang diterima, hasil diskusi kelompok terarah menunjukkan ada beberapa sumber dukungan yang dinilai sangat membantu responden, yaitu dukungan dari pasangan, keluarga besar, tenaga profesional (seperti guru, psikolog, dan dokter), agamawan dan lembaga keagamaan, lingkungan masyarakat, lembaga pemerintah, dan lembaga masyarakat. Ditinjau dari jenisnya, dukungan sosial yang dianggap sangat membantu adalah dukungan emosional dan instrumental terutama dari pasangan dan keluarga besar, dukungan emosional dari agamawan, dan dukungan informasi dari tenaga profesional. Berdasarkan hasil analisis statistik, sumber dukungan yang paling banyak diberi ranking tinggi adalah dukungan dari pasangan $(x=2.22)$, dukungan dari keluarga besar $(\bar{x}=3.34)$, dan dukungan dari kalangan profesional $(\bar{x}=3.38)$.

\section{Diskusi}

Pada tahap pertama penelitian ini, diketahui ada banyak beban yang dirasakan oleh orangtua sebagai konsekuensi dari mengasuh anak autis. Hal ini sejalan dengan beberapa penelitian terdahulu misalnya yang dilakukan oleh Lee, Harrington, Louie, dan Newschaffer [15], Lutz et al. [18], dan Whiting [31]. Beban pengasuhan yang dialami responden dalam penelitian ini dapat dikelompokkan dalam tiga dimensi. Pertama, beban yang berkaitan dengan aspek personal orangtua, misalnya menjadi lebih emosional dan kesulitan mengontrol emosi sendiri. Kedua, beban yang terkait dengan adanya hambatan yang dialami anak autis, misalnya kesulitan dalam mengontrol perilaku anak. Ketiga, beban yang terkait dengan peran pengasuhan secara umum, misalnya merasa tidak punya waktu lagi untuk diri sendiri dan bertengkar dengan pasangan atau keluarga karena berbeda pendapat dalam menangani anak. Hasil analisis statistik terhadap data yang diperoleh pada tahap dua menunjukkan bahwa skor rerata beban pengasuhan responden lebih rendah dari rerata hipotetik. Sebagian besar responden menilai beban pengasuhan yang mereka alami tergolong rendah dan sangat rendah. Hanya 16\% responden yang menilai bahwa beban pengasuhan yang mereka alami tergolong tinggi dan $29 \%$ lainnya menilai beban pengasuhan yang mereka alami tergolong sedang. Hal ini tidak menunjukkan bahwa mereka terbebas dari beban pengasuhan. Menurut Schwartz [27] beban pengasuhan merujuk pada beban secara objektif dan subjektif. Secara objektif, responden tetap mengalami kesulitan dalam aktivitas hariannya dan proses pengasuhan anak. Namun secara subjektif, mereka tidak mengalami masalah emosi dan mental yang berat. 
Hal ini tidak terlepas dari adanya faktor-faktor yang mendukung mereka untuk kuat beradaptasi terhadap beban pengasuhan, yaitu karakteristik personal dan dukungan sosial. Karakteristik personal yang membantu mereka untuk lebih kuat adalah keikhlasan menerima kondisi anak, kedekatan dengan Tuhan, kemampuan memahami kebutuhan atau keinginan anak, dan cara berpikir yang positif. Hal ini sejalan dengan penelitian yang dilakukan oleh Milshtein, Yirmiya, Oppenheim, Koren-Karie, \& Levi [22] yang menyatakan bahwa orangtua akan lebih kuat jika mereka mampu melakukan resolusi yaitu dapat menerima diagnosa anak dengan ikhlas. Hasil penelitian ini juga sejalan dengan penelitian Weiss [30] yang menemukan bahwa kemampuan orangtua untuk beradaptasi terhadap tugas mengasuh anak autis akan dipengaruhi oleh strategi koping yang mereka lakukan. Kedekatan dengan Tuhan dan cara berpikir yang positif merupakan bentuk strategi koping yang efektif untuk membantu orangtua menjadi lebih kuat.

Selain karakteristik personal, faktor lain yang membantu responden untuk kuat adalah adanya dukungan sosial, terutama dukungan dari pasangan, dari keluarga besar, dan dari profesional. Hal ini sejalan dengan penelitian yang dilakukan oleh Kapp dan Brown (2011) serta McConnell dan kawan-kawan [19] yang menemukan bahwa dukungan sosial akan meningkatkan kemampuan adaptasi keluarga terhadap permasalahan yang timbul karena kehadiran anak autis dalam keluarga.

Hasil analisis statistik juga menunjukkan bahwa beban pengasuhan yang dialami oleh ibu lebih tinggi dibandingkan dengan yang dialami oleh ayah. Hal ini tidak terlepas dari peran ibu yang biasanya dituntut untuk lebih bertanggung jawab dan banyak terlibat dalam pengasuhan anak dibandingkan ayah [8]. Dengan kondisi seperti ini, dapat dipahami kemudian jika ibu yang memiliki anak autis memiliki tingkat stres yang lebih tinggi dibandingkan dengan ayah [7];[13];[16].

\section{KESIMPULAN}

Berdasarkan hasil penelitian ini, dapat disimpulkan bahwa orangtua yang mengasuh anak autis mengalami beberapa beban pengasuhan yang dapat dikelompokkan dalam tiga dimensi. Pertama, beban yang berkaitan dengan aspek personal orangtua, misalnya menjadi lebih emosional atau kesulitan mengontrol emosi. Kedua, beban yang terkait dengan adanya hambatan yang dialami anak autis, misalnya kesulitan dalam mengontrol perilaku anak. Ketiga, beban yang terkait dengan peran pengasuhan secara umum, misalnya bertengkar dengan pasangan atau keluarga karena berbeda pendapat dalam menangani anak. Kemampuan orangtua untuk beradaptasi terhadap beban pengasuhan ini dipengaruhi oleh beberapa faktor. Pertama, karakteristik personal seperti kemampuan menerima kondisi anak dengan ikhlas dan kedekatan dengan Tuhan. Kedua, adanya dukungan sosial, seperti dukungan dari pasangan, keluarga, ataupun profesional.

\section{ACKNOWLEDGEMENT}

Kami mengucapkan terima kasih kepada beberapa lembaga terapi yang ada di Medan, khususnya Aliva Konsultan, yang telah memfasilitasi sebagian besar proses penelitian ini, mulai dari tahap pertama hingga tahap kedua. 


\section{Referensi}

[1] American Psychiatric Association (2013). Diagnostic and Statistical Manual of Mental Disorder Fifth Edition (DSM-5TM). Washington, DC: American Psychiatric Association.

[2] Baumrind, D., \& Thompson, R. A. (2002). The ethics of parenting. In M. H. Bornstein (Ed.), Handbook of Parenting, Volume 5: Practical issues in parenting (hal. 3-34). New Jersey: Lawrence Erlbaum Associates, Publishers.

[3] Berns, R. M. (2007). Child, family, school, community: Socialization and support (ed. 7). Belmont: Thomson Higher Education.

[4] Cappe, E., Wolff, M., Bobet, R., Adrien, J-L. (2011). Quality of life: a key variable to consider in the evaluation of adjustment in parents of children with autism spectrum disorders and in the development of relevant support and assistance programmes. Quality of Life Research, 20, 1279-1294. doi: 10.1007/s11136-011-9861-3.

[5] Creswell, J. W. (2010). Research design: Pendekatan kualitatif, kuantitatif, dan mixed (ed. 3).

[6] Alihbahasa: A.Fawaid. Yogyakarta: PustakaPelajar.

[7] Davis, N. O., \& Carter, A. S. (2008). Parenting stress in mothers and fathers of toddlers with autism spectrum disorders: Associations with child characteristics. Journal of Autism and Developmental Disorder, 38, 1278-1291. doi: 10.1007/s10803-007-0512-z.

[8] Finley, G. E., Mira, S. D., \& Schwartz, S. J. (2008). Perceived paternal and maternal involvement: Factor structures, mean differences, and parental roles. Fathering, 6 (1), 62-82. doi:10.3149/fth.0601.62.

[9] Ha, V. S., Whittaker, A., Whittaker, M., \& Rodger, S. (2014). Living with autism spectrum disorder in Hanoi, Vietnam. Social Science \& Medicine, 120, 278-285.

[10] Han, Y. S., \& Jun, W. P. (2013). Parental involvement in child 'e s development: Father vs. mother. Open Journal of Medical Psychology, 2 , 1-6. doi: 10.4236/ojmp.2013.24B001.

[11] Hannah, M. E., \& Midlarsky, E. (1985). Siblings of handicapped: A literature review for school psychologist. School Psychology Review, 14, $510-520$.

[12] Hoogsteen, L., \& Woodgate, R. L. (2013). The lived experience of parenting a child with autism in a rural area: Making the invisible, invisible. Pediatric Nursing, 39(5), 233-237.

[13] Kaniel, S., \& Siman-Tov, A. (2011). Comparison between mothers and fathers in coping with autistic children: a multivariate model. European Journal of Special Needs Education, 26 (4), 479-493.

[14] Karst, J. S., \& Hecke, A. V. V. (2012). Parent and family impact of autism spectrum disorders: A review and proposed model for intervention evaluation. Clinical Child and Family Psychology Review, 15, 247-277.

[15] Lee, L-C., Harrington, R. A., Louie, B. B., \& Newschaffer, C. J (2008). Children with autism: Quality of life and parental concerns. Journal of Autism and Developmental Disorders, 38, 1147-1160. doi:10.1007/s10803-007-0491-0.

[16] Little, L. (2002). Differences in stress and coping for mothers and fathers of children with Aspergeres syndrome and nonverbal learning disorders. Pediatric Nursing, 28, 565-570.

[17] Luescher, J. L., Dede, D. E., Gitten, J. C., Fennell, E., \& Maria, B. L. (1999). Parental burden, coping, and family functioning in primary caregivers of children with Joubert Syndrome. Journal of Child Neurology, 14, 642-648. doi: 10.1177/088307389901401004.

[18] Lutz, H. R., Patterson, B. J., \& Klein, J. (2012). Coping with autism: A journey toward adaptation.Journal of Pediatric Nursing, $27,206-213$. doi: 10.1016/j.pedn.2011.03.013.

[19] McConnell, D., Savage, A., \& Breitkreuz, R. (2014). Resilience in families raising children with disabilities and behavior problems. Research in Developmental Disabilities, 35, 833-848.

[20] McDermott, D. (2008). Developing caring relationships among parents, children, schools, and communities. California: Sage Publications, Inc.

[21] Miller, S. P., \& Hudson, P. (1994). Using structured parents group to provide parental support. Intervention in School and Clinic, 29 (3), 151-155.

[22] Milshtein, S., Yirmiya, N., Oppenheim, D., Koren-Karie, N., \& Levi, S. (2010). Resolution of the diagnosis among parents of children with autism spectrum disorder: Association with child and parent characteristics. Journal of Autism and Developmental Disorder, 40, 89-99. doi:10.1007/s100803-009-0837-x.

[23] Moran, P., Ghate, D., \& Merwe, A. v. d. (2004). What works in parenting support? A review of the International Evidence. Policy Research Bureau, Research Report No. 574. Diunduh dari http://dera.ioe.ac.uk/5024/1/RR574.pdf, tanggal 16 Januari 2014.

[24] Myers-Walls, J. (2004). Positive parenting: Key concepts and resources. Journal of Family and

Consumer Science, 96 (4), 10-13.

[25] Neuman, W. L. (2003). Social research methods: Qualitative and quantitative approaches (ed. 5).Boston: Pearson Education, Inc.

[26] Samadi, S. A., McConkey, R., \& Bunting, B. (2014). Parental wellbeing of Iranian families with children who have developmental disabilities. Research in Developmental Disabilities, 35, 1639-1647.

[27] Schwartz, C. (2003). Parents of children with chronic disabilities: The gratification of caregiving.Families in Society, 84 (4), $576-584$.

[28] Sipos, R., Predescu, E., Muresan, G., \& Iftene, F. (2012). The evaluation of family quality of life if children with autism spectrum disorder and attention deficit hyperactive disorder. Applied Medical Informatics, 30 (1),1-8.

[29] Stoner, C. R., \& Stoner, J. B. (2014). How we can make this work? Understanding and responding to working parents of children with autism. Business Horizons, 85-95. 
[30] Weiss, M. J. (2002). Hardiness and social support as predictors of stress in mothers of typical children, children with autism and children with mental retardation. Autism, 6 (1), 115-130.

[31] Whiting, M. (2012). Impact, meaning, and need for help and support: The experiences of parents caring for children with disabilities, lifelimiting/life-threatening illness or technology dependence.

[32] Journal of Child and Health Care, 17 (1), 92-108, doi: 10.1177/1367493512447089.

[33] World Health Organization (2004). The importance of caregiver-child interactions for the survival and healthy development of young children: A review. China: WHO Department of Child and Adolescent Health and Development. 